\title{
Comparative Analysis of Organic and Inorganic Food
}

\author{
Dr. E. Thippeswamy* \\ Associate Professor of Economics \\ Field Marshal K.M. Cariappa College Madikeri-571201 Kodagu (D)
}

\begin{abstract}
Increased use of chemicals, under intensive cultivation has disturbed the harmony existing among soil, plants and animals and human health. The extensive use of chemicals and antibiotics in inorganic food production technology has compelled the health conscious people to explore and support organic farming. The study reveals the fact that the food produced using organic methods taste better and contains a better balance of vitamins and minerals than inorganically grown food. The eating of organic food considerably reduces the heart attacks, strokes, cancer, bowel cancer, and many other diseases. Hence, importance of organic farming has increased due to its environmental friendly methods and growing consumer awareness of food safety. The role of the Government is critical in motivating the farmers switching over from inorganic farming system to organic farming system where organic farming is economically viable in the country. Besides, the government has to take appropriate measures like the separate market for organic products; announcement of support price, creation of demand by more awareness programmes, subsidy for organic inputs producers, subsidies for encouraging organic farmers; certification of farms and increase in investment on research and development activities in organic farming practices.
\end{abstract}

Key words: Organic Farming System, Inorganic Farming System, eco system, sustainability, food security, certification

\section{Background}

Agriculture sector in India has undergone significant structural changes. Inorganic farming has made the farmers of today searching for something better, in addition, farmers are pursuing chemical supplements to push crop yield, which is only harming the earth. Farmers and communities faced many socio-economic problems, particularly small farmers who found themselves increasingly marginalized due to lack of access to external inputs (Yasin 2007). Their soil is depleted from the constant application of harsh and harmful chemicals. This is particularly true in its heavy reliance on chemical fertilizers and pesticides, it depends upon subsidies and price support and external costs such as threat to other species, environmental pollution, habitat destruction and risks to human health and welfare. Besides, increase incidence of miscarriage, birth malfunctions, still births and delayed pregnancy have been documented among women agricultural workers and wives of men employed in pesticide mixing and spraying (Ranson,2002). In this background, the solution for this problem and ills of IFS now lies in Organic Farming System (OFS) a strong feeling world-over.

Organic agriculture in general is a system of crop and livestock production that promotes and enhances the health of agricultural ecosystem while providing healthy food and reflects the profound inter relationship that exists between farm biota, its production and the overall environment. Therefore, the extensive use of chemicals and anti-biotic in inorganic food production technology has compelled the health conscious people to explore and support organic farming methods in agriculture. It is generally believed that organic farming with its central focus on maintaining and improving soil health, its avoidance of pollutants, and its reliance on local inputs and labour could materially advance the economic and ecological health. Organic farming can contribute to sustainable food security by improving nutrition intake, supporting livelihoods in rural areas and enhancing biodiversity while simultaneously reducing vulnerability to climate change. In this context, the study has been undertaken to compare the quality of food produced under organic farming and Inorganic Farming Practices.

\section{Objectives of the Study}

The study is based on the following specific objectives

- To know the concepts of organic and inorganic farming.

- To study the quality of organic and inorganic food.

\section{Methodology of the study}

The study is based on secondary data which have been collected from the Government reports, national and international journals etc. In this study, the use of inorganic inputs in production of crops and rearing animals in agriculture is called conventional or modern or chemical, or inorganic agriculture, but from here onwards, it is termed as inorganic farming. On the other hand, the application of organic or natural inputs 
in the farm operations is known as organic or biodynamic or natural or biodynamic organic agriculture but it is termed as organic farming. Some of the important studies related to this area of the study have, therefore, been summarized under the following headings.

\section{Organic versus Inorganic Farming}

Organic farming though is not a 'new' concept; it was marginalized against the large-scale inorganic based farming practices that have steadily dominated food production over the years (50 years). The difference between organic and inorganic farming accounts for the most of the controversy with claims and counter claims surrounding organic agriculture methods and organic food. They are as follows;

Terry Cacek and Lind, L Langer (1986) have distinguished the organic farming from inorganic farming in the following ways. The term inorganic farming refers to a production system which employs a full range of pre and post-plant tillage practices (eg. plow, disk, plant, cultivate), synthetic fertilizers and pesticides. Therefore, inorganic farming is characterized by a high degree of crops specialization. By contrast, organic farming is characterized by a diversity of crops. Organic farmers need to borrow less money than inorganic farmers do because organic farmers buy fewer inputs such as fertilizers and pesticides. Moreover, costs and income are more evenly distributed throughout the year on diversified organic farms. The technology used in organic farming is nature based, environment friendly and sustainable. However, inorganic farming is based on synthetic fertilizer which is harmful to environment.

Subhash Chand and Sunil Pabbi (2005) made difference between organic and inorganic farming in the following ways. Products produced by organic farming are good in taste, flavor, nutritional and free from chemicals whereas products produced under inorganic farming are tasteless, less nutritious, may contain toxic residues of chemicals. Organic farming may not lead to higher production and income in the short-run as its returns are of a long-term nature. However, inorganic farming leads to higher production and income in the short-run and returns are declining in the long run. Therefore, returns from organic farming are of a long-term nature whereas returns are of short-run nature under inorganic farming.

It is increasingly felt that inorganic farming is becoming unsustainable as evidenced by declining crop productivities, damage to environment, chemical contaminations. The necessity of having an alternate agriculture method which can function in a friendly eco-system and could sustain the crop productivity is widely spread. Hence, organic farming is recognized as the best know alternative to the inorganic agriculture.

\section{Quality of Organic and Inorganic Food}

The quality and superiority of organic food production over inorganic food production has been reviewed as under.

Organic farming is becoming increasingly popular not only in India, all over the world. Many consumers are feeling disillusioned from chemically produced foods and are started to make the effort to buy organic food. The reasons are; their concern for the family members as well as the health of the environment. The good taste and nutritional value of organic food also attract the consumers. Inorganic agriculture uses a wide range of synthetic chemicals that inevitably leave residue in the produce: There are more than 130 different classes of pesticides containing some 800 entries (Plimmer, 2001). Pesticides residues enter the food chain via four main routes; on-farm pesticide use, post-harvest pesticides use, pesticide use on imported food and cancelled pesticides that persist in the environment (Kuchler et al., 1996). According to WHO estimate approximately one million people are taken ill every year with pesticides poisoning and up to 20,000 of them die in agony and a variety of reproductive health impacts on women. Increased incidence of miscarriage, birth malfunctions, still births and delayed pregnancy have been documented among women agricultural workers and wives of men employed in pesticide mixing and spraying (Ranson,2002). This is mainly due to overuse or misuse of chemicals, particularly synthetic insecticides, fungicides, herbicides, fertilizers, plant growth regulators etc that resulted in undesirable side effects not only in the agro-ecosystems, but also on human health and life systems of beneficial fauna and microorganisms. Further, the Inorganic farming's benefits have come at the cost of extensive environmental degradation and considerable health problems due to exposure to agrochemicals. The toxic residues poison the body slowly causing intensive damage to human body; the food products containing toxic pesticides residues cause heart disease, brain, kidney and liver damage and even cancer, limb deformities and poor eyesight. Thus, the extensive use of chemicals and antibiotics in inorganic food production technology has compelled the health conscious people to explore and support organic farming.

Now a day's all over the world, food safety is receiving more attention than ever before by governments and policy makers, health professionals, the food industry, the biomedical community and last but not least, the public (Crutch field and Roberts, 2000). The multiple factors have been associated with the preference for organic food that, in general, reflect an increased interest towards personal health, animal welfare and environmental protection (Makatouni, 2002). Health-related issues seem to assume greater importance than other concerns and notions about food safety are fundamental for purchasing organics (Magnusson et al., 2003; 
The United Kingdom Parliament, 1999; Lohr, 2001; Harper and Makatouni, 2002; Beharrell and Mac Fie, 1991).

A study based on data collected by the US government found pesticide residues on 23 percent of organic fruits and vegetables and nearly 75 percent of conventionally grown produce, though the residues in all the samples well below statutory limits (Baker et al., 2002). A study of three apple production system (organic integrated and conventional) in Washington state assessed their impact on some factors in all three dimensions of sustainability. They concluded that organic production systems were more profitable, had a lower environmental impact and produced sweeter and less tart apples (Reganold et al., 2001).

There is a widespread belief that organic food is significantly healthier and safer than inorganic food and consumers are willing to pay significant price premium to obtain it (Beharrell and Mac Fie, 1991). Organic farming uses almost exclusively biological and natural materials and processes to produce food. The practice aims to protect human health and conserve or enhance natural resources, with the goal to presume the quality of the environment for future generations while being economically sustainable. Hence, farmers are converting to organic methods for a variety of reasons but the most important have to do with a general unease with the health and environmental impacts of conventional practice, increasing disease and pest problems and the expectation that organic methods might be more profitable (Blobaum, 1983: Kramer, 1984: United states GAO, 1990: MacRae et al. 1990).

Singh and Dinesh Kumar (2007) have explained organic farming vis-à-vis human health and environment. The study revealed that organic farming was superior to conventional farming or chemical farming in terms of pollution free environment, good quality of food and health: conventional farming was produced food and fodder by using chemical fertilizers and pesticides, which contaminated the food, health hazardous and environment pollution. Besides, organic farming produces good quality of food, by using different plant nutrition, weed management, pest and disease management so that eating of organic food considerably reduces the heart attacks, strokes, cancer, bowel cancer and many other diseases.

Faido Magkos et. al., (2006) reported the critical and transparent overview of organic food safety to identify potential drawbacks in organic food production. The results revealed that food safety of organic verses conventional produce is difficult because of divergent conditions prevailing in terms of soil, water, climatic conditions. Organic food is not free from pesticides. However, fruits and vegetables are grown under organic farming can be found much less agrochemical residues than their conventional alternatives. Further, the health risk associated with dietary exposure to agrochemicals remains to be evaluated. Organically cultivated nitrophillic vegetables viz. leafy root and tuber were found lower content than the respective conventional ones.

Pragya Agarawal et. al., (2007) compared the quality characteristics and sensory quality in fresh green peas grown by organic, inorganic and integrated methods at Govind Ballabh Pant University of Agriculture and Technology, Pantnagar. The study found that no significant difference was observed in terms of pod length but significant difference was observed in number of seed per pod that was higher in pea grown by integrated method of cultivation. The organically grown peas scored higher total sugar, sweetness, colour, flavor and taste, besides in terms of minerals; organically grown peas had higher copper and zinc levels as compared to inorganically grown peas and peas grown by integrated method of cultivation.

Thakur et. al., (2003) examined the comparative economics of organic produce (OFS) vis-à-vis inorganic produce (IFS) in the backward and tribal hilly area of Himachal Pradesh, India. The study revealed that the poisonous and toxic inorganic chemical inputs used under IFS have turned out to be highly destructive, injurious and harmful causing large scale polluting and poisoning of soil, water, air ecosystem, agro-ecosystem, environment, plants and crop produce which in turn, induce many deadly diseases including cancer. The organic produce or organic food is best for health; more nutritious of better quality, free and safe from toxic inorganic chemical residues, looks fresh and good and tastes delicious. Hence, the health conscious buyers and consumers are buying organic produce at very high premium prices which are generally 3-4 times higher depending upon products.

In Japan, similar study was conducted by Yukio Yokoi (2002) on the policy development of organic agriculture and future perspectives. The study revealed that the public greatly concern about food safety issues owing to the recent incidents of mad cow disease (Bovine Spongiform Encephalopathy) and the detection of excess pesticide residues and the use of prohibited pesticides. Hence, policies on organic agriculture and organic food have been developed in terms of the "JAS Organic" (Japanese Agricultural Standards) accreditation system and technological support of organic farming.

Wiebel et. al., (1999) assessed fruit quality in golden delicious apple from five organic farms and five farms using integrated production methods. They found that in terms of taste, firmness, dietary fiber and phenolic compound contents, fruits from organic farms outperformed the others. Hogstad et al., (1997) examined sensory quality and chemical composition of carrots from designed trials and from organic and conventional farms. The data were analyzed using principal components and partial least squares regression to identify the main factors responsible for variation in quality. One of the most important factors was fertilizers 
application. Carrots grown with fertilizer, low levels of mineral fertilizer or with organic fertilizer, had more total sugars, stronger flavor but less crispness, protein and carotene than carrots grown with high levels of mineral fertilizer.

\section{Conclusion}

Agriculture is a critical sector of the Indian economy. Increased use of chemicals, under intensive cultivation has disturbed the harmony existing among soil, plant and animal and human health. The extensive use of chemicals and antibiotics in inorganic food production technology has compelled the health conscious people to explore and support organic farming. World organic food consumption has grown at a rate of 25 percent per annum in the last decade and it is expected to grow more than 15 percent of total food consumption in future. Moreover, the findings of the literature-reviewed reveals the fact that food produced using organic methods are taste better and contain a better balance of vitamins and minerals than inorganically grown food. The eating of organic food considerably reduces the heart attacks, strokes, cancer, bowel cancer and many other diseases. Hence, importance of organic farming has increased due to its environmental friendly methods and growing consumer awareness of food safety. The role of the Government is critical in motivating the farmers switching over from inorganic farming system to organic farming system where organic farming is economically viable in the country. Besides, the government has to take appropriate measures like the separate market for organic products; announcement of support price, creation of demand by more awareness programmes, organic inputs/subsidies for encouraging organic farmers; certification of farms and increase in investment on research and development activities in organic farming practices.

\section{References}

[1]. Baker, B., Benbrook, C., Groth III E., and Benbrook K., (2002), "Pesticide Residues in Conventional IPM-Growth and Organic Foods: Insights from Three Data Set", Food Additives and Contaminants, Vol.19 (5), May, Pp: 427-446.

[2]. Beharrell, B., and MacFie, J.H., (1991), “Consumer Attitudes to Organic Food”, Br. Food J., 93:25-30.

[3]. Blobaum, R., (1983), "Barriers to Conversion to Organic Farming Practices in the Midwestern United States", In Lockeretz, W., Edt., Environmentally Sound Agriculture, Praeger, New York, Pp:263-278.

[4]. Crutchfield, S.R. and Roberts, T., (2000), "Food Safety Efforts Accelerate in the 1990's," Food Review, 23:44-49.

[5]. Faidon Magkos Fotini Arvaniti and Antonis Zampelas, (2006), "Organic Food: Buying More Safety or Just Peace of Mind? A Critical Review of the Literature", Critical Reviews in Food Science and Nutrition, 46, pp.23-56.

[6]. Harper, G.C., and Makatoumi, A., (2002), "Consumers Perceptions of organic Food Production and Farm Animal Welfare". Br. Food J., Vol.104, pp: 287-299.

[7]. Hogstad, S., Risvik, E., and Steinsholt, K., (1997), "Sensory Quality and Chemical Composition of Carrot a Multivariate Study", Acta Agriculturae Scandinavia Section B., Soil and Plant Science, Vol.47(4), Pp: 253-264.

[8]. Kortbech-Olesen, R., (2000), "Export Opportunities of Organic Food from Developing Countries: In World Organics", Agra Europe (London) Ltd., London, UK., 9-10, May.

[9]. Kramer, D., (1984), "Problems Facing Canadian Farmers Using Organic Methods", In Pesticide Policy: The Environmental Imperative, Edited by Schrecker, T., and Vles, R., Friends of the Earth, Ottawa, Pp129-162.

[10]. Kuchler, F., Chandran, R., and Ralston, K., (1996), "The Linkage between Pesticide Use and Pesticide Residues", American Journal of Alternative Agriculture, Vol. (11), pp:161-167.

[11]. Lohr, M., (2001), "Factors Affecting International Demand and Trade in Organic Food Products", In: Regmi, A., Ed., Changing Structure of Global Food Consumption and Trade, Washington, D.C., United State Department of Agriculture (USDA), Economic Research Service, pp:67-79.

[12]. MacRae, R., Hill, S., Mehuys, G., and Henning, J., (1990), "Farm-Scale Agronomic and Economic Conversion from Conventional to Sustainable Agriculture", Advances in Agronomy. Vol. 43, pp:155-198.

[13]. Magnusson, M.K., Arvola, A., Hursti, U.K., Aberg, L., and Sjoden, P.O., (2003), "Choices of Organic Foods related to Perceived Consequences for Human Health and to Environmentally Friendly Behavior", Appetite. Vol.40, pp:109-117.

[14]. Magnusson, M.K., Arvola, A., Hursti, U.K., Aberg, L., and Sjoden, P.O., (2003), "Choices of Organic Foods related to Perceived Consequences for Human Health and to Environmentally Friendly Behavior”, Appetite. Vol.40, pp:109-117.

[15]. Makatouni, A., (2002), "What Motivates Consumer to Buy Organic Food in the UK? Results from Quantitative Study", Br.Food J., Vol.104, pp:345-352.

[16]. Muhammad Asim Yasin, (2007), “Organic Agriculture Food Security and Poverty: The Case of Pakistan", Regional Conference on Organic Agriculture in Asia, December 12-15, 2007, Bangkok, Thailand.

[17]. Plimmer, J.R., and Krieger, R., (2001), "Handbook of Pesticide Technology", 2nd (Edn.), San Diego, CA: Academic Press, pp:95 107.

[18]. Pragya Agrawal, Leena Bhattacharya, Kalpana Kulshrestha, and Mahapatra, B.S., (2007), "Effect of Organic Inorganic and Integrated Methods of Cultivation on Quality of Fresh Green Peas", Journal of Eco-friendly Agriculture, Vol.2 (1), pp.20-22.

[19]. Ransom, Pamela, (2002), "Women Pesticides and Sustainable Agriculture", Paper Presented at the Women's Caucus for the Earth Summit 2002Available:http://www.earthsummit2002.org/wcaucus/Caucus\%20position\%2020papers/agrilture/pestces1.htm.

[20]. Reganold, J.P., Glover, J.D., Andrew, P.K., and Hinman, H.R., (2001), "Sustainability of Three Apple Production Systems", Nature, 410:926-929.

[21]. Singh. Y.V., and Dinesh Kumar., (2007),”Organic Farming vis-a- vis Human Health and Environment”. Kurukshetra, Vol. 55(4), The Ministry of Rural Development, pp:3-7

[22]. Subhash Chand, and Sunil Pabbi, (2005), "Organic Farming: A Rising Concept", Ministry of Agriculture, Government of India, FICCI, Agriculture Summit 2005.

[23]. Terry Cacek, and Linda L. Langher, (1986), "The Economic Implications of Organic Farming", American Journal of Alternative Agriculture, Vol.1(1), pp25-29. 
[24]. Thakur, D.S., Sharma, K.D., Thakur, D.R., and Saini, A.S., (2003), "Economics of Production and Marketing of Organic Produce and the Burgeoning Niche Market for Organic Food Products". Indian Journal of Agriculture Marketing, Conf.Spl., (Abstract).

[25]. The United Kingdom parliament, (1999), House of Lords Select Committee on European Communities-Sixteenth Report: Organic farming and the European Union, London: The Stationery Office Limited. Available online:http://www.parliament.the-statineryoffice.co.uk/pa/ld199899/ldelect/ldeucom/93/9301.ht (assessed: October 9, 2004)

[26]. United States General Accounting Office, (1990), "Alternative Agriculture: Federal Incentives and Farmers' Opinions", GAO/PEMD-90-12. US General Accounting Office. Washington, February.

[27]. Weibel, F.P., Bickel,R., Lethold,S., Alfondi,T., Niggli,U., Foguelman,D., Lockeritz, (1999), "Are Organically Grown Apples Tastier and Healthier? A Comparative Field Study Using Conventional and Alternative Methods to Measure Fruit Quality", Proceeding of the 12th International IFOAM Scientific Conference, Mar de Plata, Argentina, November 15-29, 1998 pp:147-153.

[28]. Yokio Yokoi, (2002), "Organic Agriculture in Japan: Developing of a Labeling Scheme and Production Policies", Organic Agriculture Sustainable Markets and Policies, CABI Publications, OECD. 